\title{
Financial Analysis of Sweet Potato Farming in Gunung Talang Region, West Sumatra, Indonesia
}

\author{
Zul Irfan ${ }^{1 *}$, Khairini Syak ${ }^{2}$, Mahmud $^{2}$, and Delsi Afrini' ${ }^{2}$ \\ ${ }^{1}$ West Sumatra Assessment Institute for Agricultural Technology, Sukarami 27365, Indonesia \\ ${ }^{2}$ Faculty of Agriculture, Mahaputra Muhammad Yamin University, Solok, Indonesia \\ *Corresponding author. Email: irfanchan@yahoo.com
}

\begin{abstract}
West Sumatra province has three sweet potato's central regions, one of its is in Solok regency which is named Gunung Talang region. Farmers in this region have planted sweet potato for a long time as a secondary crop in lowland after lowland rice being harvested. Some of them planted sweet potato in upland. Sweet potato farming is an important source of income for the farmers. We have conducted a survey research in Gunung Talang region from September to November 2018. The objectives of research were to overcome the value of inputs and output of local sweet potato farming, and to analyze the farmers' sweet potato farming locally and financially. We used a purposive sampling method to select the farmers' organizations to be surveyed considering the large area of its members' sweet potato farming. The research respondents were the members of four farmers' organizations (Karya Tani 36 members, Batu Data 36 members, Karya Sari 32 members, and KWT Karya Tani 24 members). The primary data were collected through direct interview with the respondents and direct observation to their sweet potato farming. The secondary data were found through related institutions, i.e. West Sumatra Assessment Institute for Agricultural Technology, Agricultural Office of Solok regency, and Extension Office of Gunung Talang district. Results showed that the real total cost of the farmers' sweet potato farming in Gunung Talang region was IDR 12,358,655 per hectare. This cost would increase into IDR $24,635,564$ per hectare if we calculated the land revenue, interest on working capital, depreciation, rent paid for leased land, and inputed value of family labor. The average yield of the farmers' sweet potato farming was $22,550 \mathrm{~kg}$ per hectare and its price was IDR 2,300 per kg so that the total revenue was IDR 51,865,000 per hectare per planting season. The gross income gained by the farmers from sweet potato farming per hectare per planting season in Gunung Talang region was IDR 39,506,345 and the net income was IDR 27,229,436 with $\mathrm{R} / \mathrm{C}$ ratio 2.08, and $\mathrm{B} / \mathrm{C}$ ratios based on full cost basis and cash cost basis were 1.11 and 2.20, respectively. It showed that the sweet potato farming in Gunung Talang region, West Sumatra, Indonesia was financially profitable and might have been a main source of income for the farmers.
\end{abstract}

Keywords: Sweet potato, financial analysis, West Sumatra, Indonesia

\section{INTRODUCTION}

Sweet potato is the sixth most important food crop in the world, but in developing countries, it is the fifth most important food crop [1]. Data published by FAO [2] showed that in 2018, sweet potato was cultivated in 117 countries in an area of $8,062,737$ hectares producing $91,945,358$ tons. About 81.3 percent of the sweet potato production came from Asian countries. China is the leading producer within the sweet potato market responsible for more than 70 percent of global production [3]. Indonesia ranked the fifth sweet potato production following China, Malawi, Nigeria, and Uganda. The area under sweet potato cultivation in Indonesia in 2018 was 90,707 hectares with a production of $1,997,761.78$ tons [2]. In Indonesia, sweet potato is cultivated in almost all provinces, including West Sumatra [4]. For Indonesian people, sweet potato is one of the carbohydrate main resource besides rice, corn, and cassava [5]. Sweet potato is also a valuable source of vitamins B, C, and $\mathrm{E}$ for people [1].

Ten provinces are known as the central production of sweet potato in Indonesia. These are Papua, West Java, East Java, Central Java, North Sumatra, East Nusa Tenggara, South Sulawesi, West Sumatra, Bali, and North Sumawesi. West Sumatra province is the eight in term of coverage area of sweet potato farming, but it is the fifth in that of sweet potato's production [4]. Leovita et al. [6] noted that the productivity of sweet potato farming in West Sumatra is the highest among the ten central production areas of sweet potato in Indonesia.

West Sumatra province in Indonesia has three sweet potato's central regions, one of its is in Solok regency which is named Gunung Talang region. Farmers in this region have planted sweet potato for a long time as a secondary 
crop in lowland area after lowland rice being harvested. Some of them planted sweet potato in upland. Sweet potato farming has a good prospect for increasing the farmers' income [7]. In Gunung Talang region in West Sumatra, sweet potato farming is an important source of income for the farmers.

Several researches have been done by researchers related to economic analysis of sweet potato farming, either in Indonesia or other countries. Based on their research results, some researchers concluded that the sweet potato farmings were feasible. Some of them found that the sweet potato farmings were efficient; however, some other research results concluded that the sweet potato farmings were inefficient. Other researchers stated that the sweet potato farmings were profitable. We assume that the financial profitability of sweet potato farming relates to the locally specific agroecosystem, production practices, labor price, market price, and other related factors

\subsection{Related Work}

Related to financial profitability assumptions, we divided the existed work into three categories.

\subsubsection{Feasibility of sweet potato farming}

Many researches have been done by researchers related to economic analysis of sweet potato farming, either in Indonesia or other countries. Based on their research results, some researchers concluded that the sweet potato farmings were feasible. Leovita et al. [6] stated that in Ampek Angkek, West Sumatra, Indonesia, sweet potato farming was feasible based on its $\mathrm{R} / \mathrm{C}$ ratio. Factors affected the sweet potato's production in Ampek Angkek were seeds, organic fertilizer, labor in the family, and labor outside the family. In Anjarsari, West Java, Indonesia, R/C ratio of sweet potato farming also showed that sweet potato was feasible to cultivate, although $25 \%$ of its cost was for planting materials [8]. The feasibility of sweet potato farming was also mentioned by Chasanah et al. [7]. Their found that the $\mathrm{R} / \mathrm{C}$ ratios of sweet potato farming in Reban district, Batang Regency, Central Java, Indonesia were 1.07 for the planting area of 0.1-0.15 hectare, 1.36 for the planting area of $0.2-0.25$, and 1.38 for the planting area of 0.3-0.5 hectare.

\subsubsection{Efficiency of sweet potato farming}

Regarding its efficiency, El Yasin and Pudjiastutik [9] found that the sweet potato farming was efficient in Jember district, Indonesia. The total cost of sweet potato farming in that location was IDR 22,052,029, gross farm income was IDR $63,444,198$, and the net farm income reached IDR 41,392,169. However, some researchers found that the sweet potato farmings were not efficient. The sweet potato farming was inefficient in term of using farm resources in Kwara State, Nigeria, where labor shortage, poor access to improved technology and infestation by insect pests were the three most important constraints limiting sweet potato production [10]. In North Bengkulu, Indonesia, the sweet potato farming was not efficient in the use of land, planting materials, and NPK Phonska fertilizer [11]. The factor inputs in sweet potato production were inefficiently utilized in Zaria Local Government Area of Kaduna State [12]. Wie and Aidoo [13] also stated that the high cost of chemical inputs and low commodity (sweet potato) price were the most critical production and marketing constraints at the farmer level in Ghana. The inefficiency of sweet potato farming in Ampek Angkek, Indonesia, could be reduced by membership of farm group, age, and land tenure as stated by Leovita et al. [6].

\subsubsection{Profitability of sweet potato farming}

In Gogounou which is located in the North-eastern part of Benin, the production of sweet potato was economically and financially profitable, and promotion this crop could improve its profitability as part of food security and producers' welfare, stated by Paraïso et al [14]. In Camarines Sur, Philippines, Lirag [15] found that the sweet potato production is generally profitable with the high financial return of $144 \%$ to farmers. Research done by Sugri et al. [16] resulted that sweet potato production has immense potential to improve household food security, income, and nutrition in Northern Ghana. The gross profit margin and benefit-cost ratio analysis revealed that sweet potato production was profitable.

In Osun State, Nigeria, Omoare [17] found that orange flesh sweet potato was profitable, where land, labor, agrochemicals, and seeds had positive effect on sweet potato production. However, inadequate finance, poor extension service support, and inadequate market information were most serious constraints. As explained by Mfewou et al. [18], the improved varieties sweet potato cultivation has become a revenue-generating activity in the Santchou area, West-Cameroon. This crop remains an important food resource in the region and plays a role in the socio-economic improvement of the local population. Sweet potato meets the specific needs of households for their food and contributes to the economic growth of farmers.

\subsection{Our Contribution}

This paper presents the results of financial analysis of sweet potato farming in one of its central regions in Indonesia. Considering that sweet potato is one of some important food crops in the world, we reveal that how sweet potato farming becomes an important source of income for the farmers and what should be done to increase the net income of sweet potato farmings. This paper also overcomes the economic value of local cultivars of sweet potato which is planted most by the farmers. 


\subsection{Paper Structure}

The rest of the paper is organized as follows. Section 2 contains the research methodology, which includes research location, sampling method, data collection, and procedure of financial analysis. Section 3 presents the data and discussion of research results, which includes sociodemographic profiles of farmers' respondents, sweet potato production practices by the farmers, and financial analysis. Finally, Section 4 concludes the paper and presents direction for future research on mechanization and land reform policy.

\section{RESEARCH METHODOLOGY}

The study was carried out in Gunung Talang district, Solok regency, West Sumatra province, Indonesia, one of the three sweet potato regions in the province. Gunung Talang district has eight villages, i.e. Cupak, Sungai Janiah, Koto Gadang Guguk, Koto Gaek Guguk, Jawi-Jawi, Aia Batumbuak, Talang, and Batang Barus. The location lays on the highland with the altitude ranging from $813 \mathrm{~m}$ to $964 \mathrm{~m}$ above sea level.

Proportional random sampling method was used. Respondents were 32 farmers who were involved in growing sweet potato, with a minimum farm size of 0.061 hectare and maximum 0.374 hectare. All respondents were the members of four farmers' organizations named Batu Data (9 respondents), Karya Tani (9 respondents), Karya Sari (8 respondents), and KWT Karya Tani (6 respondents).

Major data collected from the surveyed respondents were: their socio-demographic profiles, cultural practices and production of sweet potato, prices and quantities of inputs and outputs used in the sweet potato production. Collection tools used were: an individual questionnaire and structured interviews. The respondents' farm size was measured directly using GPS. Finally, observations and triangulation of information were used to ensure that the collected information is accurate.

Frequency counts, weighted means and percentages were used to describe the profile of respondents and analyze the production data collected from the respondents. Agribusiness analysis was calculated in terms of its cost, revenue, income, and benefit provided guidance of Soekartawi [19]. Total cost (TC) of the sweet potato farming was calculated by counting up the paid cost (PC) and unpaid or counted cost (CC). Total revenue (TR) was calculated by multiplying yeld (Y) and the price of yield (Py). Total income (TI) was counted by decreasing TR with PC. Lastly, benefit $(\pi)$ of sweet potato farming was calculated using Mubyarto [20] formula:

$\pi=\mathrm{TI}-\mathrm{CC}$ or $\pi=\mathrm{TR}-\mathrm{TC}$ idicator of : (1) al protitability. I his ratio is per excellence an indicator of financial analysis. It expresses the total financial profit which is obtained through investing a monetary unit. Let B be all the profits made after a total investment TC and FP the financial profitability indicator. Then we have:

$$
\mathrm{FP}=\frac{\mathrm{B}}{\mathrm{TC}}
$$

In agricultural economy, $\mathrm{B}$ is the gross product obtained in value and TC all the costs expressed in value, including family labor. Thus, if GPV is the gross product value, CP the total costs that do not take into account the value of the family labor and $\mathrm{L}$ the total value of the family labor used, we have:

$$
\frac{\mathrm{B}}{\mathrm{TC}}=\frac{\mathrm{GPV}}{(\mathrm{CP}+\mathrm{L})}
$$

In economic profitability analysis, if $\mathrm{B} / \mathrm{TC}>1$, then 1 IDR invested generates more than 1 IDR as profit and the activity is said to be financially profitable. But, on the other hand, if $\mathrm{B} / \mathrm{TC}<1$, then 1 IDR invested generates less than $1 \mathrm{IDR}$ as profit and the activity is not financially profitable. Therefore the producer earns less than he invests.

\section{RESULTS AND DISCUSSION}

\subsection{Socio-demographic Profiles of Respondents}

The summary of socio-demographic profiles variables analyzed using descriptive statistics in this study is presented in Table 1. The results showed that there were more females $(59.37 \%)$ than males $(40.63 \%)$ of the farmers' respondent. The mean age of the farmers was 46.78 years old, the youngest at 29 years old and the oldest at 75 years old. In terms of the age range, most of the respondents' age clustered at young age (between 29-45 years old) with only $40.63 \%$ at $45-60$ years old and $12.49 \%$ at $60-75$ years old. This implied that they were belonged to active and productive labor force [21]. On educational attainment, $53.12 \%$ of the respondents belong to elementary level and $40.63 \%$ and $6.25 \%$ at the high school and college levels, respectively. Most of the respondents $(68.75 \%)$ have $1-4$ burdened family member with only $28.12 \%$ and $3.13 \%$ have 5-8 and 9-11 burdened family members, respectively. 
Table 1 Socio-demographic profiles of respondents.

\begin{tabular}{|l|l|c|c|}
\hline \multicolumn{1}{|c|}{ Variables } & \multicolumn{1}{|c|}{ Attributes } & Frequency & Percent \\
\hline Gender & Male & 13 & 40.63 \\
\hline & Female & 19 & 59.37 \\
\hline Age & $29-45$ years & 15 & 46.88 \\
\hline & $45-60$ years & 13 & 40.63 \\
\hline $\begin{array}{l}\text { Educational } \\
\text { attainment }\end{array}$ & $\begin{array}{l}\text { Elementary } \\
\text { level }\end{array}$ & 17 & 12.49 \\
\hline & $\begin{array}{l}\text { High school } \\
\text { level }\end{array}$ & 13 & 40.63 \\
\hline $\begin{array}{l}\text { Burden family } \\
\text { member }\end{array}$ & $1-4$ & 2 & 6.25 \\
\hline & $5-8$ & 22 & 68.75 \\
\hline & $9-11$ & 9 & 28.12 \\
\hline
\end{tabular}

Table 2 presents that most of the farmers are tenants $(65.62 \%)$ and only $34.38 \%$ of them are owners. Likewise, nearly half of the respondents $(46.88 \%)$ have a farm size of only $0.061-0.165$ hectare while $31.25 \%$ and $21.87 \%$ have a farm size 0.166-0.269 hectare and 0.270-0.374 hectare, respectively. These data shows that most of the respondents as well as the sweet potato farmers in Gunung Talang region are small farmers whose family income depends on their sweet potato farmings. Most of the respondents (84.38\%) had farming experience $1-20$ years and only $15.62 \%$ of them had farming experience more than 20 years.

Table 2 Farming characteristics of respondents.

\begin{tabular}{|l|l|l|l|}
\hline \multicolumn{1}{|c|}{ Variables } & \multicolumn{1}{|c|}{ Attributes } & Frequency & Percent \\
\hline Land tenure & Owner & 11 & 34.38 \\
\hline & Tenant & 21 & 65.62 \\
\hline Farm size & $0.061-0.165$ ha & 15 & 46.88 \\
\hline & $0.166-0.269$ ha & 10 & 31.25 \\
\hline $\begin{array}{l}\text { Farming } \\
\text { experience }\end{array}$ & $0.270-0.374$ ha & 7 & 21.87 \\
\hline & $1-10$ years & 18 & 56.25 \\
\hline & $21-30$ years & 4 & 28.13 \\
\hline & $>30$ years & 1 & 12.50 \\
\hline
\end{tabular}

\subsection{Production Practices}

The cultural management practices done by farmers for sweet potato in Gunung Talang region, West Sumatra, are the following:

- Land preparation - the area is prepared by removing all weeds, and thoroughly ploughed and harrowed twice to control immediate growth of weeds. After that, farmers hill up the land about $30 \mathrm{~cm}$ to encourage better root penetration and promote proper aeration. The spaces between the top of hills range from 80 to $100 \mathrm{~cm}$. In Gunung Talang region, farmers used unpaid family labors and hired labors for land preparation with an average number of 5.68 and 61.48 working days per hectare, respectively. Land preparation is done by male.

- Preparation of planting materials - all parts of the vines of sweet potato with $20-25 \mathrm{~cm}$ long from the terminal until $10 \mathrm{~cm}$ away from the roots are used. Most of the sweet potato farmers in Gunung Talang region plant local cultivars, i.e. Rajo Langik, Wortel, and Roti. The use of improved or national variety was not popular in the study area. The vines are collected from the self sweet potato farming or from other local farmers without cost except for labor. Preparing of planting materials is done by male and female, either unpaid family labors or hired labors.

- Planting - farmers use 1 cutting of sweet potato planted at a distance of $25-30 \mathrm{~cm}$ in a hill. Each cutting is slipped on the ridges using a sharpened stick. Planting is usually done by female of hired labors and unpaid family labors with an average number of 26.10 and 4.64 working days per hectare, respectively.

- Fertilizer application - farmers very seldom apply organic fertilizer, but usually use inorganic fertilizer. They use urea, NPK Phonska, and SS fertilizers at planting time as the basal application with an average of $91.15 \mathrm{~kg}, 128.27 \mathrm{~kg}$, and $8.42 \mathrm{~kg}$ per hectare, respectively. Not all of the farmers use these three kinds of fertilizers. Data showed that $9.38 \%$ of the respondets did not use Urea and only $12.50 \%$ of them used SS, but all of the respondents used NPK Phonska fertilizer for their sweet potato farming. The second fertilization uses NPK Phonska with an average of $128.27 \mathrm{~kg}$ per hectare 2.5 months after planting. Fertilizers are put between crops and covered by a slight soil.

- Weed control - this is done manually by pulling the grass or by using a small hoe, 5-6 weeks after planting.

- Turn over the veins - this activity is done manually every two weeks started from 2 months after planting up to 2 weeks before harvesting.

- Harvesting - farmers harvest sweet potato 4.0-4.5 months after planting. Harvest is done by cutting the vines and digging the tubers or storage roots and picking it up from the ground. Harvesting is generally done by local traders whom the farmers have initially contacted.

The average yield of sweet potato farming in Gunung Talang region was $22,550 \mathrm{~kg}$ per hectare. This yield is slightly lower than the yield of sweet potato in Anjarsari (West Java) [8], but higher than that of in Ampek Angkek region (West Sumatra) [6], and even significantly higher than the yield of sweet potato in Kepundung village (Central Java) [7], Camarines Sur (Philippines) [15], and Nigeria [22]. 


\subsection{Financial Analysis}

Table 3 shows that the farmers in Gunung Talang region applied NPK Phonska fertilizer in a highest dosage, more than $250 \mathrm{~kg}$ per hectare, for sweet potato farming. The other fertilizers they used were Urea and SS. NPK Phonska and SS are not subsidized fertilizers, Urea on the other hand is subsidized fertilizer. On an average, the farmers spent more than IDR 2,302,000 per hectare for inorganic fertilizers. The cost spent for fertilizers for sweet potato farming in Gunung Talang region is lower than that of in Ampek Angkek where is also located in West Sumatra [6]. It is because the farmers in Gunung Talang region did not use organic fertilizer for sweet potato farming. From the farmers' point of view, applying organic fertilizer has a negative effect on the quality of the sweet potato production.

Table 3 The average fertilizers used for a hectare of sweet potato farming in Gunung Talang region, West Sumatra, Indonesia, 2018.

\begin{tabular}{|l|c|c|r|}
\hline \multicolumn{1}{|c|}{ Fertilizer } & Quantity (kg) & Price per kg (IDR) & \multicolumn{1}{c|}{ Total cost (IDR/ha) } \\
\hline Urea & 91.15 & 3,500 & 319,025 \\
\hline SS & 8.42 & 7,000 & 58,940 \\
\hline NPK Phonska & 256.54 & 7,500 & $1,924,050$ \\
\hline Total & 356.11 & & $2,302,015$ \\
\hline
\end{tabular}

The farmers generally used unpaid family labors and hired labors for sweet potato farming in Gunung Talang region, West Sumatra, Indonesia. When we compare these two sources of labors, the quantity of hired labors used was higher than that of unpaid family labors, either male or female. Unpaid family labors are used for all activities in sweet potato farming. On an average, the total unpaid family labors used for one hectare of sweet potato farming were 26.63 man-days for male and 15.83 man-days for female, and its total calculated payments were IDR 1,864,100 and IDR 791,500, respectively (Table 4). The total calculated payments for unpaid family labors is only $21.06 \%$ and hired labors is $78.94 \%$ for a hectare and one planting season of sweet potato farming.

Table 4 Calculated unpaid family labors used for a hectare and one planting season of sweet potato farming in Gunung Talang region, West Sumatra, Indonesia, 2018.

\begin{tabular}{|l|c|c|c|r|}
\hline \multirow{2}{*}{\multicolumn{1}{|c}{ Activities }} & \multicolumn{4}{c|}{ Unpaid family labors } \\
\cline { 2 - 5 } & Male & Price (IDR) & Female & Price (IDR) \\
\hline Collecting plant materials & 2.87 & 200,900 & 6.37 & 318,500 \\
\hline Land preparation & 5.68 & 397,600 & - & - \\
\hline Planting & - & - & 4.64 & 232,000 \\
\hline Weed control & 5.95 & 416,500 & 4.82 & - \\
\hline Fertilization & 6.13 & 429,100 & - & - \\
\hline Turn over the veins & 6.00 & 420,000 & - & 791,000 \\
\hline \multicolumn{1}{|c|}{ Total } & 26.63 & $1,864,100$ & 15.83 & \\
\hline
\end{tabular}

The hired labors were also used for all activities in sweet potato farming in Gunung Talang region, West Sumatra, Indonesia. On an average, the total hired labors used for one hectare of sweet potato farming were 105.10 man-days for male and 52.00 man-days for female. It means that $79.78 \%$ of male and $76.66 \%$ of female labors were hired. Farmers usually spent as much as IDR 7,357,000 and
IDR 2,600,000 to pay the male and the female hired labors for one hectare and one planting season of sweet potato farming, respectively (Table 5). The total calculated payments for unpaid family labors is only $21.06 \%$ and hired labors is $78.94 \%$ for a hectare and one planting season of sweet potato farming. 
Table 5 Hired labors used for a hectare and one planting season of sweet potato farming in Gunung Talang region, West Sumatra, Indonesia, 2018.

\begin{tabular}{|l|c|r|r|r|}
\hline \multirow{2}{*}{ Activities } & \multicolumn{3}{|c|}{ Hired labors } \\
\cline { 2 - 5 } & Male & Price (IDR) & Female & Price (IDR) \\
\hline Collecting plant materials & 5.79 & 405,300 & 7.01 & 350,500 \\
\hline Land preparation & 61.48 & $4,303,600$ & - & $1,305,000$ \\
\hline Planting & - & - & 26.10 & 944,500 \\
\hline Weed control & 20.33 & $1,423,100$ & 18.89 & - \\
\hline Fertilization & 0.87 & 60,900 & - & - \\
\hline Turn over the veins & 16.63 & $1,164,100$ & - & $2,600,000$ \\
\hline \multicolumn{1}{c|}{ Total } & 105.10 & $7,357,000$ & 52.00 & - \\
\hline
\end{tabular}

Table 6 presents the cost and returns for sweet potato farming in Gunung Talang region. Sweet potato is cultivated in Gunung Talang region in lowland after lowland rice being harvested. In the staudy area, farmers predominately cultivated local cultivars. On an average, the sweet potato area allocated by farmers was only 0.20 hectare. Fertilization of sweet potato applied by the farmers varied greatly. The average yield of sweet potato in Gunung Talang region was $22,550 \mathrm{~kg}$ per hectare which was higher than the national average yield in 2018 [23]. On an average, farmers were selling sweet potato storage roots at the rate of IDR 2,300 per kg. It was calculated that the gross cost of IDR 24,635,564 was incurred for cultivation of sweet potato in one ha. Labor cost was calculated to be IDR 9,957,000 while material cost was IDR 2,401,655. Operational cost for cultivating one ha of sweet potato was IDR 21,979,964. The cost of production of sweet potato was calculated to be IDR 1.092 per $\mathrm{kg}$ of storage roots. Gross income of IDR $51,865,000$ and a net income of IDR 27,229,436 were obtained from one hectare of sweet potato farming. Benefitcost ratio (BCR) was found to be 1.105 .

The production cost of sweet potato farming included all variable cost items like labor, materials, and others used in the production of sweet potato. Both cash expenditures and inputed value of family owned inputs have been included in the calculation. Human labor was required for different farm operations like land preparation, collecting planting materials, planting, fertilization, weed control, and turn over the veins. Human labor constituted the highest cost in Gunung Talang region (51.52\%) (Table 6). More than 131 man-days per hectare were employed to produce sweet potato (Table 4 and 5). Out of 131 man-days, 105.10 were hired and 26.63 were unpaid family supplied. This condition is the same as sweet potato farming in Arjasari, Bandung regency where the use of hired labors were dominant compared to unpaid family labors [8] but is different from human labors used for sweet potato farming in Sherpur and Jamalpur districts in Bangladesh [24] where total labors used were 284 mandays and 274 mandays, and the number of unpaid family labors were higher than hired labors. Consequently, the benefit-cost ratio of sweet potato farming in Gunung Talang region was lower than that of in Bangladesh, either full cost basis or cash cost basis. In Odisha, India, the cost and returns analysis of sweet potato farming indicated that the labor cost accounted for $42 \%$ of the total cost of production and the sweet potato production was profitable [25].

The results obtained from the cost-benefit ratio of sweet potato farming presented in Table 6 indicate that IDR 1 invested in the production of sweet potato generates IDR 1.105. It means that sweet potato farming in Gunung Talang region is financially profitable. In other words, farmers gain on each invested IDR, 0.105 IDR that is a bit more than the capital they have invested in the production of this crop. The results tally with those of other researchers obtained for sweet potato farming in other locations in Indonesia like Ampek Angkek in Agam regency (benefit-cost ratio 0.86) [6] and in Reban, Batang regency with the highest revenuecost ratio 1.38 [7], but lower than that of in Arjasari, Bandung regency with benefit-cost ratio 1.24 [8] and in Pati, Jember regency (benefit-cost ratio 1.88) [9]. In other words, the production of sweet potato in Gunung Talang region is financially more profitable than that of in Ampek Angkek and Reban but less profitable than that of in Arjasari and Pati. Not only sweet potato farming, even the sweet potato trading also had a net positive return. In Sierra Leone in 2018 , for example, the benefit-cost ratio of sweet potato trading was greater than one, indicated that sweet potato trading business was profitable [26]. 
Table 6 Cost and farm income measures for sweet potato farming in Gunung Talang region per hectare.

\begin{tabular}{|c|c|c|c|c|}
\hline Particulars & Unit & Price per unit (IDR) & Total (IDR) & $\%$ to total \\
\hline \multicolumn{5}{|l|}{ Labor costs: } \\
\hline $\begin{array}{l}\text { Land preparation } \\
\text { (male) }\end{array}$ & 61.48 & 70,000 & $4,303,600$ & 17.47 \\
\hline $\begin{array}{l}\text { Collecting planting } \\
\text { materials: } \\
\text { - Male } \\
\text { - Female }\end{array}$ & $\begin{array}{l}5.79 \\
7.01\end{array}$ & $\begin{array}{l}70,000 \\
50,000\end{array}$ & $\begin{array}{l}405,300 \\
350,500\end{array}$ & 3.07 \\
\hline Planting (female) & 26.10 & 50,000 & $1,305,000$ & 5.30 \\
\hline Fertilization (male) & 0.87 & 70,000 & 60,900 & 0.25 \\
\hline $\begin{array}{l}\text { Weed control: } \\
\text { - Male } \\
\text { - Female }\end{array}$ & $\begin{array}{l}20.33 \\
18.89\end{array}$ & $\begin{array}{l}70,000 \\
50,000\end{array}$ & $\begin{array}{r}1,423,100 \\
944,500\end{array}$ & 9.61 \\
\hline $\begin{array}{l}\text { Turn over the veins } \\
\text { (male) }\end{array}$ & 16.63 & 70,000 & $1,164,100$ & 4.73 \\
\hline Gross labor costs & & & $9,957,000$ & 40.42 \\
\hline \multicolumn{5}{|l|}{ Material Costs } \\
\hline Fertilizers: & & & & 9.34 \\
\hline $\begin{array}{l}\text { - Urea } \\
\text { - SS } \\
\text { - NPK Phonska }\end{array}$ & $\begin{array}{c}91.15 \\
8.42 \\
256.54\end{array}$ & $\begin{array}{l}3,500 \\
7,000 \\
7,500\end{array}$ & $\begin{array}{r}319,025 \\
58,940 \\
1,924,050\end{array}$ & \\
\hline Sack & 49.82 & 2,000 & 99,640 & 0.40 \\
\hline Gross material cost & & & $2,401,655$ & 9.75 \\
\hline Land revenue & & & 138,230 & 0.56 \\
\hline $\begin{array}{l}\text { Interest on working } \\
\text { capital }\end{array}$ & & & $1,373,579$ & 5.58 \\
\hline Depreciation & & & 109,500 & 0.44 \\
\hline Cost A & & & $13,979,964$ & 56.75 \\
\hline $\begin{array}{l}\text { Rent paid for leased } \\
\text { in land }\end{array}$ & & & $8,000,000$ & 32.47 \\
\hline Cost B & & & $21,979,964$ & 89.22 \\
\hline $\begin{array}{l}\text { Imputed value of } \\
\text { family labor }\end{array}$ & & & $2,655,600$ & 10.78 \\
\hline Cost $\mathrm{C}$ & & & $24,635,564$ & 100.00 \\
\hline \multicolumn{5}{|l|}{$\begin{array}{l}\begin{array}{l}\text { Farm income } \\
\text { measures }\end{array} \\
\end{array}$} \\
\hline Yield (kg) & & & 22,550 & \\
\hline $\begin{array}{l}\text { Price } / \mathrm{kg} \text { of storage } \\
\text { roots }\end{array}$ & & & 2,300 & \\
\hline Gross Income & & & $51,865,000$ & \\
\hline Net income & & & $27,229,436$ & \\
\hline Revenue-Cost ratio & & & 2.079 & \\
\hline $\begin{array}{l}\text { Benefit-Cost ratio: } \\
\text { Full cost basis } \\
\text { Cash cost basis }\end{array}$ & & & $\begin{array}{l}1.105 \\
2.203\end{array}$ & \\
\hline
\end{tabular}




\section{CONCLUSION}

The study examined the value of inputs and output of local sweet potato farming and to analyze the farmers' sweet potato farming locally and financially. Sweet potato farming in Gunung Talang region, West Sumatra, Indonesia is financially profitable with the benefit-cost ration based on full cost basis and cash cost basis were 1.11 and 2.20, respectively. Sweet potato farming gives the gross income for the farmers more than IDR 39,506,000 and the net income more than IDR 27,229,000 per hectare per planting season. The sweet potato farming can be a main source of income for the farmers. The average yield of sweet potato in Gunung Talang region was $22,550 \mathrm{~kg}$ per hectare. The productivity can be increased through the improvement of varieties and its cultural practices. The highest cost of sweet potato's farming inputs is for hired labor $(40.42 \%)$ and rent paid for leased in land (32.47\%). Related to this, this study recommends to develop mechanization technology of sweet potato farming in order to reduce the labor cost. Land reform can be considered to increase the farmers' access for farm land. This can result in the mass growing of sweet potato which can also increase the farmers' income.

\section{ACKNOWLEDGMENT}

We sincerely acknowledge the contribution of the agricultural extensionists of Gunung Talang Agricultural Extension Office for their companion and a researcher of West Sumatra Assessment Institute for Agricultural Technology who has helped in measuring the definite coverage area of sweet potato farming of all farmers's respondents. We are also indebted to the anonymous reviewers for their very helpful comments on the draft of the manuscript.

\section{REFERENCES}

[1] CIP, 'Sweet potato facts and figures', Int. Potato Center, Lima, Peru, 2018.

[2] FAO, 'FAO Statistics', Food and Agric. Organization, Rome, Italy, 2020.

[3] Shahbandeh, 'Global potato production 2002-2018, Potato production worldwide from 2002 to 2018', Statista, Hamburg, Germany, 2020.

[4] BPS-Statistics Indonesia, 'Statistical Yearbook of Indonesia 2019', Jakarta, 2019.

[5] D. A. A. Elisabeth, 'Added value improvement of taro and sweet potato commodities by doing snack processing activity', Procedia Food Science, vol. 3, pp. 262-273, 2015, doi: 10.1016/j.profoo.2015.01.029
[6] A. Leovita, R. W. Asmarantaka, H. KS. Daryanto, 'Income analysis and technical efficiency of sweet potato farming in Ampek Angkek district, Agam regency, West Sumatra province', J. Agribisnis Indonesia, vol. 3, no. 1, pp. 11-24, 2015.

[7] L. Chasanah, L. A. Sasongko, R. Subantoro, 'Feasibility analysis of sweet potato Ipomoea batatas $L$.) farming variety Cilembu in Kepundung village, Reban district, Batang regency', MEDIAGRO, vol. 14, no. 2. pp. 19-28, 2018. (Indonesian)

[8] H. Hapsari, E. Rasmikayati, A. Karuniawan, B. R. Saefudin, 'Farmers' characteristics and profile of sweet potato farming in Anjarsari district, Bandung regency', Sosiohumaniora - J. of Soc. Sci. and Humaniora, vol. 21, no. 3, pp. 247- 255, 2019 (Indonesian), doi: 10.24198/sosiohumaniora.v21i3.21288

[9] M. S. El Yasin, E. W. Pudjiastutik, 'Analysis of farming income of sweet potato (Ipomoea batatas L.) in village of Panti, sub-district Panti, district Jember', J. Agribest, vol. 3, no. 2, pp. 101-104, 2019, doi: 10.32528/agribest.v3i2.2325 (Indonesian).

[10] A. G. Addeyonu, O. L. Balogun, B. O. Ajiboye, I. B. Oluwatayo, A. O. Otunaiya, 'Sweet potato production efficiency in Nigeria: Application of data envelopment analysis', IMS Agri. and Food, vol. 4, no. 3, pp. 672-684, 2019, doi: 10.3934/agrfood.2019.3.672

[11] B. Simanjuntak, K. Sukiyono, Sriyoto, 'Analysis of production function and allocative efficiency of sweet potato farming in Hulu Palik subdistrict of North Bengkulu district', J. AGRISEP, vol. 18, no. $1,2019$.

[12] A. Yusuf, Y. T. Wuyah, 'Economic analysis of small scale sweet potato production in Zaria local government area of Kaduna State', Amer. J. of Econ., Finance and Management, vol. 1, no. 3, pp. 171-178, 2015.

[13] P. Wie, R. Aidoo, 'Analysis of the sweet potato value chain in Ghana; Linkages, pathways, governance and constraints', J. Agric. Food. Tech. vol. 7, no. 1, pp. 1-13, 2017, doi: https://doi.org/10.1155/2017/8767340

[14] A. A. Paraïso, A. C. G. Sossou, A. Sanni, S. F. Tokoudagba, R. N. Yegbemey, 'Analysis of sweet potato (Ipomoea batatas L.) production in the commune of Gogounou, Benin', Int. J. of Sci. and Adv. Tech., vol. 2, no. 11, pp 46-53, 2012.

[15] Ma. T. B. Lirag, 'Determinants of profitability of sweet potato production in Camarines Sur, Philippines', Int. J. on Adv. Sci. Engin. Inf. Tech., vol. 9, no. 2, pp. 467-473, 2019.

[16] I. Sugri, B. K. Maalekuu, E. Gaveh, F. Kusi, 'Sweet potato value chain analysis reveals opportunities for increased income and food security in Northern 
Ghana', Hindawi Advances in Agriculture, vol. 2017. Article ID 8767340, 14p, doi: https://doi.org/10.1155/2017/8767340

[17] A. M. Omoare, 'Analysis of profitability of orange flesh sweet potato (Ipomoea batatas) in Osun State, Nigeria', J. Agric. Sci. \& Env., vol. 18, no. 1 \&2, pp. 140-150, 2018.

[18] A. Mfewou, F. D. Engwali, P. Tchofo, 'Geography of the production of Ipomoea batatas (sweet potato): An analysis in the space of Santchou (West-Cameroon)', SSRG Int. J. of Humanities and Social Sci. (SSRG-IJHSS), vol. 6, no. 2, pp. 67-72, 2019.

[19] Soekartawi, 'Farming Analysis', UI Press, Jakarta, 2003. (Indonesian).

[20] Mubyarto, 'Introduction to Agricultural Economics', LP3ES, Jakarta, 2003. (Indonesian).

[21] Harlen and D. Setiawan, 'Productive age perspective facing demographic bonuses in Riau province', Amer. J. of Econ., vol. 9, no. 1 pp. 2337, 2019, doi: 10.5923/j.economics.20190901.05

[22] J. C. Udemezue, 'Profitabilities and constraints to sweet potato production in Nigeria', Curr Trends
Biomedical Eng. \& Biosci., vol. 19, no. 2, 2019, doi: 10.19080/CTBEB.2019.19.556007

[23] Ministry of Agriculture, 'Agricultural Statistics 2018', The Indonesian Ministry of Agriculture, 2019. (Indonesian)

[24] M. A. Awal, S. R. Saha, M. M. Khaled, M. A. Khan, 'An economic analysis of sweet potato cultivation in some selected char areas of Bangladesh', J. Bangladesh Agril. Univ., vol. 5, no. 1, pp. 159-167, 2007.

[25] P. Prakash, P. Kishore, Jaganathan D., S. Immanuel, P.S. Sivakumar, 'Status, performance and impact of sweet potato cultivation on farming communities of Odisha, India', in: 30th International Conference of Agricultural Economists, Vancouver, 2018.

[26] O. Nabay, M. Koroma, A. J. Johnson, F. S. Kassoh, 'Analysis of the profitability and marketing distribution channels of sweet potato business in Sierra Leone', J. Agric. Ext. Rural Dev., vol. 12, no. 2, pp. 26-35, 2019, doi: 10.5897/JAERD2019.1123 